\title{
Thyroid Cancer Pathologic Regional Lymph Nodes TNM Finding v6
}

National Cancer Institute

\section{Source}

National Cancer Institute. Thyroid Cancer Pathologic Regional Lymph Nodes TNM

Finding v6. NCI Thesaurus. Code C60870.

A pathologic finding about one or more characteristics of thyroid cancer, following the rules of the TNM AJCC V6 classification system as they pertain to staging of regional lymph nodes. TNM pathologic regional lymph nodes findings are based on clinical findings supplemented by histopathologic examination of one or more tissue specimens acquired during surgery. 